\title{
Arvustused
}

Epi Tohvri, Georges Frédéric Parrot: Tartu Keiserliku Ülikooli esimene rektor (Tartu: Tartu Ülikooli Kirjastus, 2019), 1071 lk, ISBN: 978-994903-143-6.

Rahvusülikooli juubeliaastal jõudis lugejateni Epi Tohvri mahukas monograafia Keiserliku Tartu Ülikooli esimesest rektorist Georges Frédéric Parrot'st. Parrot' nimi ei vaja ajaloohuvilisele tutvustamist, ent terviklik käsitlus tema elust ja tegevusest seni puudus. Nüüd on see lünk vähemalt eestikeelse lugeja jaoks täidetud. Parrot' erakordne, tänapäeva mõistes multidistsiplinaarne haare ning avar tegutsemisväli Prantsusmaal, Saksamaal, Liivimaal ja Peterburis seab teda käsitlevale autorile ülikõrged nõudmised, mistõttu tuleb eriti tunnustada Epi Tohvri julgust see töö nii mastaapselt ette võtta ning tema järjekindlust see lõpuni viia. Autor on küll hariduselt kunstiajaloolane ning on ametis Tallinna Tehnikaülikoolis arhitektuuriajaloo dotsendina, ent oma varasemates teadustöödes ei ole ta piirdunud arhitektuuri stiiliajaloolise analüüsiga, vaid on vaadelnud ka ehitiste retoorilist funktsiooni ühiskonnas, pöörates tähelepanu ühiskondlikele ja hariduslikele ideedele, mis arhitektuurse keskkonna loomist mõjutasid. Retsenseeritav teos on nii meetodi kui ka teemade poolest kasvanud välja just nendest uurimustest. Juba oma 2009. aastal kaitstud doktoritöös, mis vaatles valgustusideede mõju Tartu Ülikooli 19. sajandi arhitektuuriansambli kujunemisele, rõhutas Tohvri Parrot' juhtivat rolli ülikooli arhitektuuriansambli kontseptsiooni väljatöötamisel, tuues ta sel viisil välja kälimehe J. W. Krause varjust. Käesoleva teose eesmärgiks võib pidada Parrot' veelgi ulatuslikumat unustusest väljatoomist, ${ }^{1}$ pidades sealjuures silmas mitte ainult Tartu Ülikooli või Balti provintside ajaloo kitsamat konteksti, vaid ühiskondlik-poliitilisi ning hariduslik-teaduslikke arenguid Vene keisririigis tervikuna.

Raamat jaotub viieks suuremaks osaks, millest esimene käsitleb Parrot' perekondlikku tausta, noorusaastaid Montbéliardis, Stuttgardis ja

\footnotetext{
1 Vt ka autori enda selgitusi Margus Maidla, "Vähehinnatud suurmees Georges Frédéric Parrot", Sirp, 07.07.2017.
} 
Pariisis, saabumist Liivimaale 1795. aastal ning esimesi tegutsemisaastaid siinse teadus- ja hariduselu organiseerimisel. Teise raamatu raskuskese nihkub Tartust Peterburi ning vaatluse alla võetakse Parrot' erisuhe keiser Alexander I-ga ning tema tegevus keisri nõuandjana erinevates ühiskondlik-poliitilistes küsimustes. Kolmas osa keskendub spetsiifilisemalt impeeriumi hariduspoliitikale ja võtab fookusesse Parrot' hariduskavad, mis ei piirdunud võitlusega Tartu Ülikooli autonoomia eest, vaid seadsid eesmärgiks tervikliku, mitteseisusliku ja pragmaatilise haridussüsteemi loomise kogu keisririigis. Neljas osa on jätkuvalt Peterburi-keskne, käsitledes peamiselt Parrot' hariduskavu ja ühiskondlikke vaateid Nikolai I ajal, ent heites pilgu ka Parrot' initsiatiivil loodud Tartu Professorite Instituudi käekäigule. Viimane osa on pühendatud Parrot' kui füüsikaprofessori teadlaskarjäärile, mille juures on tähelepanu pööratud nii tema avastustele, leiutistele ja ehitusprojektidele kui ka suhetele ja võrgustikele Euroopa "õpetlasvabariigis".

Monograafia kõige suurem tugevus on allikakesksus. Autor on teinud põhjalikku uurimistööd Eesti, Läti, Venemaa ja Prantsusmaa arhiivides ja raamatukogudes ning toonud teaduskäibesse suure hulga seni kasutamata materjale Parrot' kõigi eluperioodide ja tegevusvaldkondade kohta. Uurimuse tuum ja võib-olla ka kõige väärtuslikum osa on Parrot' kirjad ja märgukirjad Venemaa keisritele, mis moodustavad märkimisväärse osa raamatu mahust (prantsuskeelsed tekstid on sujuvasse eesti keelde tõlkinud Marge Käsper). Teose näol ongi sisuliselt tegu hübriidiga allikapublikatsioonist ja teaduslikust monograafiast, mis kohati meenutab saksa kultuuriruumist tuntud žanri "Materialien zur..." stiilis käsitlusi. Mõni alapeatükk on tervikuna käsitletav pigem allikapublikatsioonina, koosnedes lühikesest sissejuhatusest ja 5-6 lehekülje pikkusest allikatsitaadist. Sellise hübriidžanri valikul on omad eelised. Arusaadavalt ei saa autor end pidada eksperdiks igas teemavaldkonnas, milles Parrot'-taoline multitalent sõna võttis, mistõttu allikate pea tervikuna esitamine aitab ära hoida võimalikke väärtõlgendusi või oluliste aspektide väljajätmist, mida analüütilisem ja kokkuvõtlikum stiil oleks võinud kergesti kaasa tuua. Nii leiab avaldatud dokumentidest palju ka selliseid mõtteid ja ideeliine, millele autor pole osanud või pidanud vajalikuks tähelepanu pöörata, aga mis teiste uurijate jaoks võivad osutuda tänuväärt materjaliks Läänemereprovintside teaduskultuuri ja ühiskondliku mõtte edasisel uurimisel.

Teiseks, hübriidžanri viljelemine laseb allikatel endil pikalt kõnelda, nii et maksvusele pääseb mitte ainult allikateksti sisuline sõnum, vaid ka stiil, mida autor peab ka ise tähtsaks, tõstes esile Parrot' prantsuse keele 
elegantsi. Lisaksin juurde, et oluline on ka sõnumit saatev retoorika ehk viis, kuidas Parrot' oma ideid keisritele serveeris. Tohvri rõhutab Parrot' rolli sõbra või "tõerääkijana", ent mõistagi on siinkohal tegu absolutismiajal väljakujunenud fiktsiooniga, mis peegeldas komplitseeritud vastastikuseid ootusi piiramatu võimuga isevalitseja ja tema ametlike või mitteametlike nõunike vahel. Juba antiikajast on tuntud õpetused valitsejatele, kuidas vältida meelitajaid, sest monarh vajas adekvaatset informatsiooni ja toimivaid nõuandeid olukorras, kus tema lähikondlastel oli sageli tugev ahvatlus lipitseda. Samas on selge, et päris ilustamata tõtt ei talunud ükski isevalitseja, mistõttu on Parrot' kirjad põnev näide balansseerimisest leebe kriitika ja varjatud meelitamise piirimaadel.

Allikad ei hakka siiski iseseisvalt kõnelema, mistõttu autor pöörab õigusega tähelepanu Parrot'ga seotud materjalide ajaloolise konteksti rekonstrueerimisele. Jälle saab tunnustada autori suurt tööd, aga samas tuleb ka nentida, et tulemus jääb ebaühtlaseks. Mõnda teemaliini on tutvustatud äärmise põhjalikkusega. Näiteks haridusküsimuse puhul pälvivad Rzeczpospolita 1783. aasta haridusseadus (lk 369-374) või Venemaa 1863. aasta haridusreform (lk 829-835) lausa omaette alapeatüki, ehkki üks neist võeti vastu aastaid enne Parrot' Liivimaale jõudmist ning teine pärast tema surma, mistõttu nende seos Parrot' hariduskavadega on pigem kaudne. Kui Parrot' enda tekstide puhul on ülipikad allikatsitaadid põhjendatavad, siis konteksti tutvustamisel oleks kindlasti kohasem kokkuvõtlikumat ja ülevaatlikumat laadi kirjutamisviis. Kõrvalisemad teemad paisutavad tarbetult raamatu mahtu (kokku $1071 \mathrm{lk}$ ), samas kui mõned olulised taustaarengud, näiteks Venemaa konstitutsiooniprojektide ajalugu aastatel 1805-32, mis aitaks selgitada Parrot' poliitiliste vaadete arengut ja keiser Nikolai I-le esitatud soovitusi (lk 794-798), jäävad visandamata. Samuti oleks tahtnud näha terviklikumat käsitlust Aleksander I valitsuse algusperioodi valgustuslikest reformikavadest, millel oli keisrikojast laiem ühiskondlik kandepind. Selle asemel annab autor tihtipeale järele ahvatlusele teha põikeid kõrvalistele teemadele. Omapärase kurioosumina on näiteks ligi kaks lehekülge kulutatud Gustav Adolf Hippiuse portreesarjale, millel pole Parrot'ga üldse pistmist. Näib, et autor ei ole tahtnud leppida biograafilisest žanrist tulenevate paratamatute temaatiliste piirangutega, ent sellisel juhul tulnuks pigem eluloolisest lähenemisest loobuda.

Teiseks autori esitusviisiga kaasnevaks probleemiks on see, et paljudel juhtudel ei ole esitatud kontekst analüütiliselt seotud Parrot' tegevuste ja märgukirjadega, st pärast tausta avamist ja Parrot'ga seotud allika tsiteerimist jätab autor järelduste tegemise lugeja teha, selmet täpsemalt näidata, 
millisel viisil eespool tutvustatud mõttevoolud ja ideed Parrot' vaateid kujundasid - või vastupidi, millisel määral ja viisil Parrot' ettepanekud ja projektid hilisemat praktikat mõjutasid. ${ }^{2}$ Samuti oleks tahtnud näha uurimistulemuste tugevamat suhestamist varasema historiograafia seisukohtadega. Autor ei viita alati uusimale kirjandusele, vaid on sageli toetunud 19. sajandi või 20. sajandi alguse autoritele, samas kui teemat on käsitletud ka kaasaegses ajalookirjanduses. ${ }^{3}$ Nii jätab autor kasutamata potentsiaali revideerida oma põhjaliku arhiivitöö alusel tänapäeva historiograafia seisukohti või vähemalt näidata, millisel viisil Parrot' isikuga arvestamine täiendab varasemaid seletusskeeme. ${ }^{4}$ Kokkuvõttes jääb töö nõrgalt seotuks ajalooteadusliku diskussiooniga. Antud kriitika ei ole siiski mõeldud niivõrd etteheitena, kuivõrd osutusena edasisele potentsiaalile, mida monograafias esitatud materjal pakub nii autorile endale kui ka teistele uurijatele.

Sisu poolest on kõige tugevamad need peatükid, mis käsitlevad Parrot' tegevust ja vaateid haridus- ja kasvatusküsimustes. Niisamuti on väga põhjalik ja veenev ülevaade Parrot' ehitusprojektidest, eriti tema panus Tartu ja Pulkovo observatooriumite rajamisse. Parrot' teadustegevus on esitatud samuti suure põhjalikkusega. Ehkki alati ei ole selge, millisel määral olid Parrot' teaduslikud ideed adekvaatsed ja innovaatilised oma kaasaegse teaduse kontekstis, näitab Tohvri veenvalt Parrot' metodoloogia teadusloolisi juuri ning määratleb tema suhtlusringi ja positsiooni Euroopa teadlaskogukonnas. Kahtlemata on Tohvri teinud suurepärast tööd ka Parrot' elukäigu ja isiklike suhete rekonstrueerimisel.

Vähem veenvad on need osad, mis käsitlevad Parrot' ühiskondlikke ja poliitilisi vaateid. Ei saa vaielda teesiga, et Prantsuse (või täpsemalt Prantsuse-Šveitsi) valgustus on väga oluline mõjutegur Parrot' vaadete kujunemisele, ent Tohvri frankofiilne seletusskeem jääb liiga ühekülgseks. Veelgi enam, ka prantsuse kultuuriruumi mõttelugu on Tohvri käsitluses peaaegu täielikult taandatud füsiokratismile. "Füsiokraatlikeks" on nimetatud selliseid üldisi hoiakuid ja ideid, mis on omased ka paljudele teistele mõttesuundadele ning autoritele, kes ei pooldanud seda spetsiifilist poliitökonoomilist doktriini. Nii on teiste hulgas füsiokraadiks muutunud ka Diderot (lk 375), kes tegelikult hoopis teravalt kritiseeris füsiokraatlikke

2 Lk 184 hindab autor Parrot' konstitutsiooniprojekti mõjukust selle järgi, millises arhiivifondis seda on säilitatud.

3 Lk 118 viitab autor 1816/1819 a talurahvareformide puhul Villem Reimani "Eesti ajaloole".

4 Mõned rahvusvaheliselt tunnustatud autorid, kelle üldkäsitlusi oleks tasunud kasutada: Alexander M. Martin, Julia Berest, Marc Raeff, James C. McClelland, Franklin Walker, Nicholas Hans. 
reformiprojekte. ${ }^{5}$ Autori käsitluses on füsiokraatia muutunud valgustusliku ja progressiivse mõtteviisi sünonüümiks, aga sel juhul kaotab mõiste oma sisu. Samal ajal jätab autor käsitlemata ühe olulise aspekti füsiokraatlikus doktriinis, nimelt legaalse despotismi idee, mis küll toetas monarhi ainuvõimu, ent üritas piirata tema meelevald set valitsemist "loomulikule korrale" vastavate seaduste, avaliku arvamuse ja regionaalse detsentraliseerimise kaudu. Eristus despootia ja seaduste abil valitseva monarhia vahel on Parrot' jaoks ilmselgelt oluline ning vääriks uurimist, kuivõrd ta toetus sellekohaste ideede puhul Montesquieu'le (kelle mõjutused on selgelt märgatavad, nt lk 821, 824) ning kuivõrd teistele autoritele, sh füsiokraatidele. Füsiokraatide ratsionalistlik utoopia võis tõepoolest sobida Parrot'le, kes oli üks neist paljudest läänepoolse Euroopa idealistidest, kes tulid Venemaa "valgustatud despootidele" nõu andma ning olid enamasti sunnitud pettuma. Aga samas toetusid tema ideed erinevatele mõttevooludele. Võtame näiteks Parrot' tugeva toetuse manufaktuuride rajamisele, mille puhul võis ta hoopis tugineda füsiokratismi kriitikutele (nt Ferdinando Galiani), kes rõhutasid riske, mis tulenevad ühekülgselt põllumajandusele orienteeritud majandusmudelist. Edasi toob autor küll välja saksa kultuuriruumis domineerinud kameraalteaduste tähtsuse Parrot' Stuttgardis omandatud hariduses, ent ei analüüsi sisuliselt, millisel viisil kameralism tema vaateid mõjutas ning kuidas see haakus füsiokraatlike ideedega.

Täielikult on autori tähelepanu alt välja jäänud õiguslik ning õigus- ja moraalifilosoofiline ideestik, eriti loomuõiguse ja sellega seonduv inimõiguste idee, mis on ometigi korduv teemaliin Parrot' tekstides. Sümptomaatiline on, et loomuõigust (le droit naturel) on teoses tõlgitud vähemalt kolmel erineval moel: "loomulik õigus" (lk 221), "loomuõigus" (lk 440) ja "loodusõigus" (lk 474). Õigusmõistete kasutuses valitseb üldse paras segadus, näiteks "rahvaste õigus" (prawa narodów, lk 475) on tõlgitud tähendustmuutvalt kui "rahvaste seadused" ning Dorpati tsiviilõiguse professuur (bürgerliches Recht) on tõlkes täiesti kaotsi läinud ja muutunud "kodanikuõiguste" professuuriks (lk 524). Läbisegi on kasutatud "natuurfilosoofia" ja "loodusfilosoofia" mõisteid. Ka teoste pealkirjades oleks võinud järgida Eestis väljakujunenud tõlketraditsiooni, näiteks Rousseau puhul jääda "Ühiskondliku lepingu" juurde. Tohvril on selle kohta lausa kaks konkureerivat varianti, mis kumbki ei lähtu senisest tõlketavast: "Sotsiaalne kokkulepe” (lk 91) ja “Sotsiaalne leping” (lk 797). Mis puutub Parrot'

5 Vt nt Timothy Hochstrasser, "Physiocracy and the politics of laissez-faire", ed. by Mark Goldie and Robert Wokler, The Cambridge History of Eighteenth-Century Political Thought (Cambridge University Press, 2006), 427, 435. 
loomuõiguskäsitluse lähtealustesse, siis neid otsides jõuame füsiokraatide või Prantsuse valgustajate asemel tegelikult hoopis Immanuel Kanti juurde, kelle ideele inimesest kui eesmärgist, mitte kui vahendist Parrot korduvalt toetub (lk 190, 439).

Teine sõna lisaks "füsiokraatiale", mis muutub oma laialivalguvuse tõttu sisutühjaks, on "liberalism". Autor nimetab Parrot'd "veendunud liberaaliks", ent autor ei täpsusta, mida liberalism Venemaa kontekstis tähendas ning kuidas see oli ühildatav Parrot' usuga valgustatud monarhiasse ning paternalistliku retoorikaga tema keisritele saadetud kirjades. Parrot' võis ju tõepoolest muutuda Nikolai I võimuperioodi ajaks mingis mõttes liberaalsemaks võrreldes 1805. aastaga, kui ta oli tagasi lükanud Venemaa konstitutsiooni idee ja pooldanud pigem legaalset despotismi. Aga kindlasti ei olnud see John Stuart Milli liberalism, mis seadis eesmärgiks piirata riigivõimu sekkumist tsiviilühiskonna toimimisse. Kuna autor selliseid eristusi ei tee ega uuri ka Parrot' vaadete dünaamikat, kipub teoses kujunema Parrot'st kriitikavaba, staatiline ja pooltoonideta pilt kui kõigi heade ja progressiivsete mõtete kandjast ning eetilisest majakast, kes terve elu oli sunnitud võitlema tagurlike ja omakasupüüdlike konservatiivide ja reaktsionääridega.

Mis puudutab teose vormistuslikku külge, siis raamatule annab lisaväärtust rohke illustreeriv pildimaterjal, mis aitab ajastut lugeja jaoks visualiseerida. Küll aga oleks teos vajanud enne trükkitoimetamist põhjalikumat korrektuuri, sest silma torkavad rohked trüki- ja poolitusvead, samuti kordused, kus täpselt samad laused on esitatud nii teksti põhiosas kui ka viidetes (lk 546, 913, 1002).

Vaatamata neile kriitilistele nootidele on tegu äärmiselt tähelepanu- ja tänuväärse teosega Eesti alal tegutsenud suurmehest, mis läbi eluloolise prisma maalib terve ajastu ühiskondlike, kultuuriliste ja teaduslike arengute avara panoraamvaate. Raamatust saavad ammutada rohket inspiratsiooni, mõtteainet ja materjali nii praegused kui ka tulevased ajaloolased. Teos võiks kindlasti pakkuda huvi ka laiemale lugejaskonnale, eriti arvestades, et mitmed selle kesksed teemad, mis puudutavad näiteks humanistlikke haridusideaale, kodanike moraalset kasvatust ja teaduse autonoomiat, ei ole pelgalt ajaloolised, vaid kõlavad vastu ka tänapäeval. ${ }^{6}$

\section{PÄrtel PiIrimäe}

6 Arvustuse valmimist on toetanud Eesti Teadusagentuur (PRG318) ja Euroopa Liidu Regionaalarengu Fond (Eesti-uuringute tippkeskus), ning see on seotud Eesti Haridusja Teadusministeeriumi uurimisprojektiga IUT20-5. 